\title{
FIRST DETECTION OF PORCINE CIRCOVIRUS TYPE 3 IN UKRAINE
}

\author{
N. G. Rudova*, O. Yu. Lymanska, B. T. Stegniy, \\ V. I. Bolotin, O. S. Solodiankin, A. P. Gerilovych \\ National Scientific Center "Institute of Experimental and Clinical Veterinary Medicine" \\ 83, Pushkinska Str., Kharkiv, Ukraine, 61023 \\ E-mail:runavet@gmail.com*; olagaliman@ukr.net; boris.stegniy@gmail.com; \\ vbolotin@hotmail.de; olexii.solod@gmail.com; antger2011@gmail.com
}

Received May 04, 2021 / Received June 15, 2021 / Accepted July 19, 2021

\begin{abstract}
To date, there is no information regarding the occurrence of porcine circovirus type 3 (PCV-3) in pigs in Ukraine. Aim. The aim of this work was to study the probable occurrence of the little-studied PCV-3 in pigs with different health status in Dnipropetrovsk, Donetsk, Kyiv, and Kharkiv regions of Ukraine. Methods. Blood, semen, liver, spleen, lung samples and nasal swabs of sows and boars of different ages and with different health status, belonging to farms from Dnipro, Donetsk, Kyiv, and Kharkiv regions of Ukraine, were used for the study. PCV-3 genomic material was detected by the standard polymerase chain reaction using specific primers, flanking a fragment of the rep gene of the virus with the length of $418 \mathrm{bp}$. To visualize the amplicons, horizontal gel electrophoresis was used and ethidium bromide staining after electrophoresis, followed by photographing the gels using Image Lab 5.2.1 software. Results. DNA of PCV-3 was found in two liver samples and four nasal swabs in two different farms, obtained from clinically healthy pigs, which suggests the possibility of the circulation of this infectious agent at the subclinical level of infection at the farm under investigation. No PCV-3 coinfection with the causative agents of porcine reproductive and respiratory syndrome (PRRS), Aujeszky's disease, PCV-2, and mycoplasmas was found at this farm. Conclusions. Porcine circovirus type 3 (PCV-3) - (a little-studied causative agent of swine disease) was detected in 6 out of 61 samples, originating from two farms in the Kyiv and Kharkiv regions, obtained from clinically healthy animals) for the first time in Ukraine. This indicates possible circulation of the pathogen among pig farms in Ukraine and demonstrates the need to create and implement a target risk analysis, an extensive survey, as well as to develop control measures of the disease spreading (both organizational and technical preventive). Molecular genetic surveying and subsequent monitoring of PCV-3 among domestic and wild animals, which can cross the borders, will give a possibility to determine the risks of its spreading and related economic and epidemiological consequences. The whole-genome DNA sequencing of the detected virus isolates is planned to determine the relation of Ukrainian strains of the virus to other strains circulating in Europe and other parts of the world. Better understanding the risks, epidemiology and pathology, associated with this new virus for the Ukrainian pig breeding industry, will help to prevent and control its further spread and harmful effects.
\end{abstract}

Key words: DNA, polymerase chain reaction, porcine circovirus type 3 .

DOI: https://doi.org/10.15407/agrisp8.02.016

\section{INTRODUCTION}

Porcine circoviral infection (PCVI) is currently one of the most wide-spread economically significant diseases for the global pig population, since it brings heavy losses to the pig breeding industry in the whole world due to the death of piglets in the process of grow-

(C) N. G. RUDOVA, O. Yu. LYMANSKA, B. T. STEGNIY, V. I. BOLOTIN, O. S. SOLODIANKIN, A. P. GERILOVYCH 2021 ing and finishing, insufficient weight gain, losses due to reproduction pathology, inefficient treatment with antibiotics, irrational use of antibiotics, and decreased quality of pig breeding products (Kekarainen $\mathrm{T}$ et al, 2015; Streltsova YuB et al, 2018; López-Lorenzo $\mathrm{G}$ et al, 2019). PCVI is reported in all the countries with developed pig breeding industry; this disease is further characterized by significant immunosuppression and multi-organ nature of the pathology. The PCVI agent is a single-stranded DNA virus - porcine 
circovirus type 2 (PCV-2) from the Circoviridae family. Two strains of PCV have been long known: PCV-1 and PCV-2, the circulation of which has been described from the USA, Canada, the EU, and other Euro-Asiatic countries: India, China, Republic of Korea, South Korea. Switzerland (Wang Y et al, 2020; Opriessniq T et al, 2014; Saporiti V, Huerta E et al, 2020; Mukherjee P et al, 2018; LV et al, 2020; Kim S-C et al, 2018; Oropezaq-Moe M et al, 2017). PCV-1 is a contaminant of cell cultures and does not cause the disease in pigs (Shen $\mathrm{H}-\mathrm{G}$ et al, 2012). PCV-2 is characterized by significant pathogenicity and is the reason for many syndromes and diseases of pigs (Segales J et al, 2005). In 2016, there was a report about detecting a new type of porcine circovirus - PCV-3 in sows with reproductive failures and clinical signs of porcine dermatitis and nephropathy syndrome (DNS) in North Carolina (Palinski R et al, 2016). In the same year, the presence of PCV-3 in pigs with multi-systemic inflammation in North America was described (Phan TG et al, 2016). At present, PCV-3 has been reported from Asia (Bera BC et al, 2020; Qi S et al, 2019; Hayashi S et al, 2018; Kwon $\mathrm{T}$ et al, 2017), South and North Americas (Serena MS et al, 2020; Saraiva GL et al, 2019; Vargas-Bermudez DS et al, 2019), and in many European countries: Ireland, Denmark, Italy, Spain, Great Britain, Germany, Sweden, Poland, and the Russian Federation (Saporiti V et al, 2021; Czyżewska-Dors E et al, 2020; Deim $\mathrm{Z}$ et al, 2019; Klaumann F et al, 2018; Yuzhakov AG et al, 2018; Faccini $S$ et al, 2017; Stadejek T et al, 2017). PCV-3 is associated with different clinical syndromes, including abortion and reproductive failure of pigs, porcine dermatitis and nephropathy syndrome, cardiac and multi-systemic inflammation, and respiratory diseases (Jiang $\mathrm{H}$ et al, 2019; Ouyang T et al, 2019; Phan TG et al, 2016). PCV-3 was also found in latently infected pigs (without clinical symptoms) (Saporiti V, Cruz TF et al, 2020; Savic B et al, 2020). The virus is frequently detected in the form of coinfections with other infectious agents, including PCV2 and porcine reproductive and respiratory syndrome virus (Serena MS et al, 2020; Sukmak M et al, 2019; Chen $\mathrm{N}$ et al, 2019). It was found that with time the rate of coinfection at pig farms may increase (Wang $\mathrm{Y}$ et al, 2020). The retrospective studies demonstrate that PCV-3 has been circulating not only among domestic pigs but also in the populations of wild boars for decades (Prinz C et al, 2019). The rate of wild boar PCV-3 infection may fluctuate from 23 to $50 \%$ (Prinz $\mathrm{C}$ et al, 2019) and amount to $61.54 \%$ (Giudici S et al,
2020). It shows that wild boars may be also a potential reservoir of PCV-3 for Ukraine, and thus may present some risks of infecting industrial pig populations and pigs at homestead farms as some of the farms provide free keeping of animals in certain areas, which have an insufficient level of biological protection (Varela APM et al, 2020).

In Ukraine, traditionally a country with developed pig breeding as a key branch of farming industry, the epizootic situation with PCV-3 is yet to be studied. The total population of pigs in Ukraine is $6.1 \mathrm{mln}$ and $2.4 \mathrm{mln}$ of them are kept in backyards (http://www.ukrstat.gov. ua/). Our study is the first preliminary, small screening on the circulation of PCV-3 - phylogenetically "the youngest" circovirus, described only in 2016 (Palinski R et al, 2016; Phan TG et al, 2016; Shen H et al, 2018). The detection and (un)known distribution of PCV-3 in countries, bordering Ukraine ((Deim Z et al, 2019; Yuzhakov AG et al, 2018; Stadejek T et al, 2017)), present the risks of introducing (PCV-3 strains from abroad, which may be a threat to the domestic pig breeding. Therefore, the aim of this work was to investigate the possible presence of PCV-3 among pigs in Dnipro, Donetsk, Kyiv, and Kharkiv regions of Ukraine.

\section{MATERIALS AND METHODS}

To conduct this study, we used 61 samples of different biological material: blood, semen, liver, spleen, lung samples and nasal swabs of sows and boars, collected from pigs of different age, belonging to the farms of Dnipro, Donetsk, Kyiv, and Kharkiv regions, sampled in the framework of routine surveying for other pig diseases.

The total DNA was extracted from the samples of biological material obtained by the method of Boom $\mathrm{R}$ et al, 1999.

The genomic DNA of PCV-3 was detected in a conventional PCR, using PCV-3 specific primers PIF (forward primer, 5'-ttgtggtgctacgagtgtcc-3') and PIR (reverse primer, $5^{\prime}$-cgtctccgtcagaatccgag- $3^{\prime}$ ) at the concentration in the reaction mixture of $0.2 \mu \mathrm{mol}$, the target for which was the conserved rep gene region (ORF1) of the virus, 418 bp (Saporiti V, Cruz TF et al, 2020).

The PCR was conducted using ThermoScientific DreamTaq and Green PCR Master Mix (2X), according to the manufacturer's instructions (https://www. thermofisher.com/order/catalog/product/K1081\#/ K1081), with a Biometra TAdvanced thermal cycler (Germany) using the following protocol: initial de- 
naturation $95{ }^{\circ} \mathrm{C}$ for $1 \mathrm{~min}$; denaturation $95{ }^{\circ} \mathrm{C}$ for $95 \mathrm{~s}$, annealing $60{ }^{\circ} \mathrm{C}$ for $30 \mathrm{~s}$, elongation $72{ }^{\circ} \mathrm{C}$ for $30 \mathrm{~s}$; number of cycles - 40 (Saporiti V, Cruz TF et al, 2020).

The 418 bp amplicon of the PCV-3 rep gene cloned in plasmid vector $\mathrm{pBLUNT}$, was used as a positive control for PCR (kindly provided in the framework of a joint project by the Lanzhou Veterinary Research Institute, the People's Republic of China). Nuclease free water was used as negative control.

The amplification results were visualized by horizontal electrophoresis in $1.5 \%$ agarose gel with $10 \mu 1$ of the amplification product at $12 \mathrm{~V} / \mathrm{cm}$ for $40 \mathrm{~min}$. Gels were stained with ethidium bromide. The amplicon length was determined using a molecular mass marker GeneRuler 100 bp DNA Ladder, ThermoScientific. The amplification results were documented in the photo documentation program Image Lab 5.2.1 using a BioRad Universal Hood II transilluminator.

\section{RESULTS}

We used in total 61 samples of blood $(\mathrm{n}=13)$, sperm $(n=3)$, liver $(n=10)$, spleen $(n=4)$, lungs $(n=1)$, or swabs from mucous membranes $(n=30)$, obtained from sows and boars with different health status, but without specific clinical symptoms for PCV-3, at the farms in Dnipropetrovsk, Donetsk, Kyiv, and Kharkiv regions of Ukraine. The biological material (except for the liver) initially came to the molecular diagnostics laboratory to be tested for the presence of genomic material of porcine reproductive and respiratory syndrome (PRRS), Aujeszky's disease, PCV-2 and Mycoplasma spp.

Six of the 61 samples, from two different farms, were found positive regarding the presence of the genetic material of PCV-3 (Table 1).

Table 1. The results of investigations on biological material samples of pigs regarding the presence of PCV-3 genomic material

\begin{tabular}{l|c|c|c|c}
\hline \multirow{2}{*}{ Region } & \multirow{2}{*}{$\begin{array}{c}\text { No } \\
\text { of } \\
\text { farms }\end{array}$} & \multicolumn{2}{|c|}{$\begin{array}{c}\text { Number } \\
\text { of investigated samples }\end{array}$} & $\begin{array}{c}\text { Share } \\
\text { of positive } \\
\text { samples, } \\
\%\end{array}$ \\
\cline { 4 - 5 } & & total & positive & \\
\hline Dnipro 1 & 1 & 11 & 0 & 0.0 \\
Donetsk 1 & 1 & 10 & 0 & 0.0 \\
Kyiv 1 & 1 & 30 & 4 & 13.33 \\
Kharkiv 1 & 1 & 10 & 2 & 20.0 \\
Total & & 61 & 6 & 9.8 \\
\hline
\end{tabular}

The specific DNA fragment of PCV-3 of 418 bp was found in two liver samples of pigs from Kharkiv region (Fig. 1) and four nasal swabs of clinically healthy pigs from Kyiv region (Fig. 2). Coinfection of PCV-3 with other infectious agents was not established.

Thus, the obtained results of PCR-screening including testing of 61 samples from pigs showed the presence of PCV-3 in apparently latently infected pigs in two farms in the Kyiv and Kharkiv region in Ukraine.

\section{DISCUSSION}

Porcine circovirus type 3 (PCV-3) is a new, relatively little-studied agent, the studies on which started only five years ago. Historically, this is the "youngest" porcine circovirus in the world (Klaumann $\mathrm{F}$ et al, 2018). The serological tests, developed on the basis of indirect enzyme immunoassay, allowed conducting the retrospective study on PCV-3 in the pig population in China which demonstrated an increase in the number of PCV-3-positive cases from 22.35 to $51.88 \%$ in three years (Deng $\mathrm{J}$ et al, 2018), and the examination of the population of sows at the farms of China, the results of which demonstrated the spreading with the seroprevalence more than $50 \%$ (of PCV-3 among both clinically healthy sows and the animals with reproductive failures (Zhang $S$ et al, 2019). Some studies showed, that (Q) PCR is more effective for PCV-3 diagnostics in compare to serological methods or in situ hybridization (Kedkovid R et al 2018 At present, PCV-3 detection is mostly based on the use of molecular genetic methods using different PCR formats (Rodrigues ILF et al, 2018; Fux R et al, 2018; Liu Y et al, 2019; Dal Santo AC et al, 2020) and amplification technologies (Ji J et al, 2019; Ye X et al, 2018; Zheng S et al, 2018).

Although PCV-3 pathogenicity has not been sufficiently proven (Klaumann F et al, 2018), but the genetic organization of circoviruses may pose a risk by the transfer of foreign genes allowing them to overcome the interspecies barrier (Gibbs MG et al, 1999; Firth $\mathrm{C}$ et al, 2009). The pathogenicity and risk of porcine circoviruses for humans has been described as negligible already in 2013 and no infections have been found in humans since, but transfer cannot be totally excluded (Burbelo P et al, 2013).

The conventional PCR format was successfully used with the purpose of monitoring and diagnostics, for instance, in testing blood serum of pigs of samples originating from different European countries analyzed in the study of Saporiti et al, 2020), the results of which 


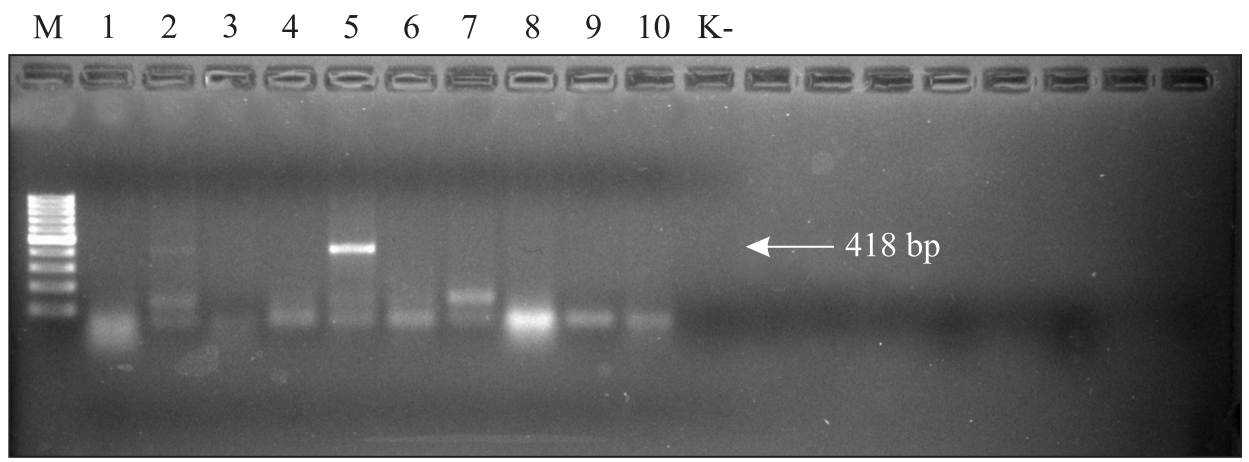

Fig. 1. The visualization of amplification results for the fragment of genomic DNA of PCV-3, extracted from the liver homogenate of clinically healthy pigs from the farm in Kharkiv region. 1-10 - the samples of DNA, extracted from the liver homogenate of clinically healthy pigs (including positive samples 2 (weakly positive) and 5 (strongly positive); $\mathrm{M}$ - molecular mass marker; K- - negative control of amplification

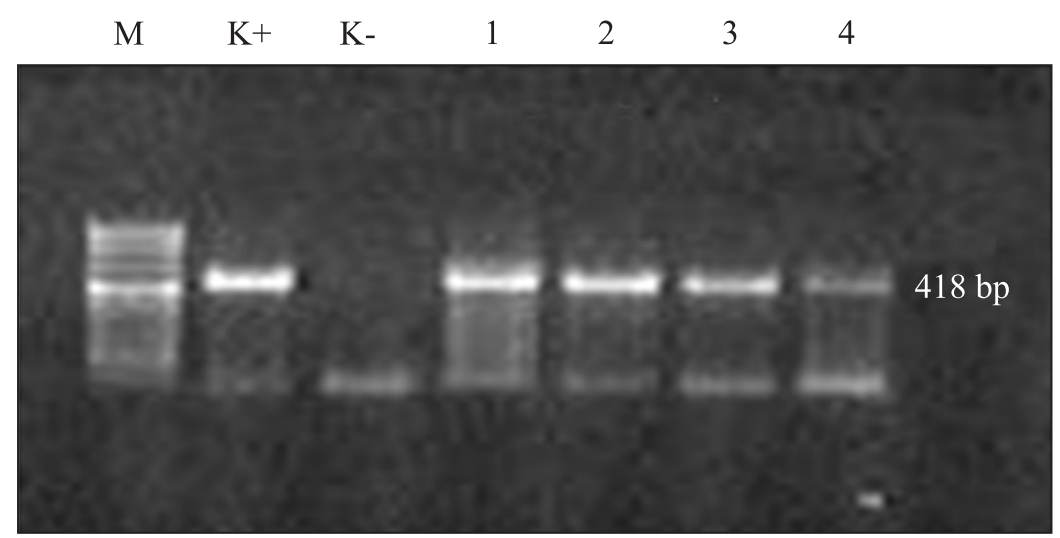

Fig. 2. The amplification results for the rep gene of PCV-3, extracted from the liver homogenate of 4 clinically healthy pigs from the farm in Kyiv region: $\mathrm{M}$ - molecular mass marker; $\mathrm{K}+-$ - positive control of amplification; $\mathrm{K}-\mathrm{-}$ - negative control of amplification; $1-4-$ positive samples

demonstrated a fluctuation in the level of infecting the animals from 4 to $15 \%$.

Conventional PCR was also used in the first investigation of PCV-3 in China using the biological material of the pigs from the farms, located in 11 provinces and districts of the country ( $\mathrm{Ku} \mathrm{X}$ et al, 2017), and to conduct the retrospective study on various biological material, obtained from wild boars in Spain (Klaumann F et al, 2019). PCV-3 genetic material was found in blood serum, heart tissue, lungs, spleen, kidneys, intestines, oral fluid, lymph nodes, brain of the animals of different gender and age, tissues of aborted fetuses and stillborn piglets (Klaumann F et al, 2019; Ku X et al, 2017; Hayashi S et al, 2018). We used the samples of clinical material, collected in earlier monitoring of porcine circoviral infection and other pig diseases in Ukraine (Rudova N, 2020).

Thus, the obtained results of PCR screening of samples of biological material from pigs showed the presence of PCV-3 in the pig population in Ukraine.

\section{CONCLUSIONS}

For the first time, porcine circovirus type 3 (PCV-3) was detected in 6 biological samples (liver and nasal swabs), obtained from clinically healthy animals from a farm in the Kharkiv and from a farm in the Kyiv region in Ukraine. This indicates possible, till now undetected, and more widespread circulation of the pathogen among pig farms in Ukraine than initially suspected. It necessitates a target risk analysis and development of preventive and control measures to reduce the possibilities of further spread of this, often symptomless, virus. More extensive molecular genetic surveying and monitoring of PCV-3 to determine its real presence and spread is necessary. The whole-genome DNA sequencing of the detected virus isolates is planned to determine the relation of Ukrainian strains of the virus to other strains circulating in Europe and other parts of the world. Better understanding the risks, epidemiology and pathology, associated with this new virus for the Ukrainian pig 
breeding industry, will help to prevent and control its further spread and harmful effects.

Adherence to ethical principles. All experiments described in this paper were non animal based.

Conflict of interests. The authors declare the absence of any conflicts of interests.

Financing. This study was conducted with the state support according to "United health, biological, and food safety" program within the framework of the fundamental scientific research "The study on specificities of the molecular-genetic structure of little-studied agents of the diseases of pigs and cattle in the territory of Ukraine (PCV-3, Hepatitis E virus, Bovine immunodeficiency virus, Bovine spumavirus) and determination of targets to be identified via molecular biotechnologies" (state registration 0121U108362).

\section{Перший випадок виявлення в Україні цирковірусу свиней типу 3}

Н. Г. Рудова*, О. Ю. Лиманська, Б. Т. Стегній, В. І. Болотін, О. С. Солодянкін, А. П. Герілович

Національний науковий центр «Інститут експериментальної і клінічної ветеринарної медицини», Вул. Пушкінська, 83, Харків, Україна, 61023

e-mail: runavet@gmail.com*; olagaliman@ukr.net; boris.stegniy@gmail.com; vbolotin@hotmail.de; olexii.solod@gmail.com; antger2011@gmail.com

На сьогодні відсутні дослідження щодо поширення цирковірусу свиней типу 3 серед поголів'я свиней на території України. Мета. Дослідити ймовірність поширення маловивченого цирковірусу свиней типу 3 серед поголів'я свиней 3 різним статусом здоров'я на території Дніпропетровської, Донецької, Київської та Харківської областей України. Методи. Для дослідження використано зразки крові, сперми, гомогенатів печінки, селезінки, легень та змивів зі слизових оболонок, отримані від свиней та кнурів різного віку і різним статусом здоров'я, що належали господарствам Дніпропетровської, Донецької, Київської та Харківської областей України. Детекцію геномного матеріалу збудника здійснювали шляхом стандартної полімеразної ланцюгової реакції з використанням системи праймерів, фланкуючих специфічний фрагмент гена гер ЦВС-3 довжиною 418 пар нуклеотидів. Для візуалізації ампліконів використовували метод горизонтального гель-електрофорезу 3 наступним фотографуванням гелів з використанням програмного забезпечення Image Lab 5.2.1. Результати. ДНК ЦВС-3 виявлено у двох зразках печінки та чотирьох зразках змивів зі слизових оболонок носової порожнини отриманих від клінічно здорових свиней 3 двох різних господарств, що дозволяє припустити можливість циркуляції зазначеного збудника серед тварин, досліджених в цих господарствах, на фоні субклінічної інфекції. Коінфекції ЦВС-3 зі збудниками респіраторно-репродуктивного синдрому свиней, хвороби Ауєскі, цирковірусу свиней типу 2 та мікоплазмами встановлено не було. Висновки. Вперше детектовано генетичний матеріал нового для України вірусного виду - цирковірусу свиней типу 3 (Porcine circovirus type 3) - нового маловивченого збудника захворювання свиней - у біологічних зразках, отриманих від клінічно здорових тварин. Це свідчить про можливість циркуляції даного збудника у свиногосподарствах на території України та необхідність розробки та впровадження таргетного ризиканалізу та розроблення заходів контролю щодо його поширення (організаційних i профілактичних). Проведення молекулярно-генетичного моніторингу ЦВС3 серед поголів'я свійських та диких тварин, здатних перетинати кордони країни, дасть змогу з'ясувати рівні ризиків його поширення i пов'язаних з ними економічних, господарчих та епідеміологічних наслідків. Планується проведення повногеномного секвенування ДНК виявлених ізолятів вірусу задля визначення відношення українських ізолятів вірусу до інших ізолятів, що циркулюють у Свропі та інших частинах світу. Краще розуміння ризиків, епідеміології та патології, пов'язаних з цим новим для галузі свинарства України вірусом, допоможе запобігти та контролювати його подальше поширення та шкідливі наслідки.

Ключові слова: ДНК, полімеразна ланцюгова реакція, цирковірус свиней типу 3 .

\section{REFERENCES}

Bera BC, Choudhary M, Anand T et al. (2020) Detection and genetic characterization of porcine circovirus 3 (PCV3) in pigs in India. Transbound Emerg. Dis. 67: 1062-1067. https://doi.org/10.1111/tbed.13463.

Boom R, Sol CJ, Salimans MM et al. (1990) Rapid and simple method for purification of nucleic acids. J. Clin. Microbiol. 28:495-503. https://doi.org/10.1128/ jcm.28.3.495-503.1990.

Burbelo PD, Ragheb JA, Kapoor A, Zhang Y. (2013) The serological evidence in humans supports a negligible risk of zoonotic infection from porcine circovirus type 2 . Biologicals. 41:430-434. https://doi.org/10.1016/j.biologicals.2013.09.005.

Chen N, Huang Y, Ye M et al. (2019) Co-infection status of classical swine fever virus (CSFV), porcine reproductive and respiratory syndrome virus (PRRSV) and porcine circoviruses (PCV2 and PCV3) in eight regions of China from 2016 to 2018. Infection, Genet. Evolut. 68:127-135. https://doi.org/10.1016/j. meegid.2018.12.011.

Czyżewska-Dors E, Núñez JI, Saporiti V et al. (2020) Detection of porcine Circovirus 3 in wildlife species in 
Spain. Pathogens. 9:341. https://doi.org/10.3390/pathogens 9050341 .

Dal Santo AC, Cezario KC, Bennemann PE et al. (2020) Full-genome sequences of porcine circovirus 3 (PCV3) and high prevalence in mummified fetuses from commercial farms in Brazil. Microbial. Pathogen. 141: 104027. https://doi.org/10.1016/j.micpath.2020.104027.

De Conti ER, Resende TP, Marshall-Lund L et al. (2021) Histological Lesions and Replication Sites of PCV3 in Naturally Infected Pigs. Animals. 11:1520. https://doi. org/10.3390/ani11061520.

Dei Giudici S, Franzoni G, Bonelli P et al. (2020) Genetic characterization of porcine circovirus 3 strains circulating in Sardinian pigs and wild boars. Pathogens 9:344. https://doi.org/10.3390/pathogens9050344.

Deim Z, Dencső L, Erdélyi I et al. (2019) Porcine circovirus type 3 detection in a Hungarian pig farm experiencing reproductive failures. Veterin. Rec. 185:84-84. https:// doi.org/10.1136/vr.104784.

Deng J, Li X, Zheng D et al. (2018) Establishment and application of an indirect ELISA for porcine circovirus 3. Arch. Virol. 163:479-482. https://doi.org/10.1007/ s00705-017-3607-7.

Faccini S, Barbieri I, Gilioli A et al. (2017) Detection and genetic characterization of Porcine circovirus type 3 in Italy. Transbound Emerg. Dis. 64:1661-1664. https://doi. org/10.1111/tbed.12714.

Firth C, Charleston MA, Duffy S et al. (2009) Insights into the Evolutionary History of an Emerging Livestock Pathogen: Porcine Circovirus 2. J. Virol. 83:1281312821. https://doi.org/10.1128/JVI.01719-09.

Franzo G, Legnardi M, Centelleghe C, et al. (2018b) Development and validation of directPCR and quantitative PCR assays for the rapid, sensitive, and economical detection of porcine circovirus 3. J. Vet. Diagn. Invest. 30(4):538-544. doi: 10.1177/1040638718770495.

Franzo G, Legnardi M, Hjulsager CK et al. (2018) Fullgenome sequencing of porcine circovirus 3 field strains from Denmark, Italy and Spain demonstrates a high within-Europe genetic heterogeneity. Transbound Emerg. Dis.; 65:602-606. https://doi.org/10.1111/tbed.12836.

Fux R, Söckler C, Link EK et al. (2018) Full genome characterization of porcine circovirus type 3 isolates reveals the existence of two distinct groups of virus strains. Virol. J. 15:25. https://doi.org/10.1186/s12985018-0929-3.

Gibbs MJ, Weiller GF. (1999) Evidence that a plant virus switched hosts to infect a vertebrate and then recombined with a vertebrate-infecting virus. Proc Nat. Acad. Sci. 96:8022-8027. https://doi.org/10.1073/pnas.96.14.8022.

Hayashi S, Ohshima Y, Furuya Y et al. (2018) First detection of porcine circovirus type 3 in Japan. J. Veter. Med. Sci. 80:1468-1472. https://doi.org/10.1292/jvms.18-0079.

Ji J, Xu X, Wang X et al. (2019) Novel polymerase spiral reaction assay for the visible molecular detection of porcine circovirus type 3. BMC Vet. Res. 15:322. https:// doi.org/10.1186/s12917-019-2072-9.

Jiang H, Wang D, Wang J et al. (2019) Induction of Porcine Dermatitis and Nephropathy Syndrome in Piglets by Infection with Porcine Circovirus Type 3. J. Virol. https:// doi.org/10.1128/JVI.02045-18.

Kedkovid R, Woonwong Y, Arunorat J et al. (2018) Porcine circovirus type 3 (PCV3) infection in grower pigs from a Thai farm suffering from porcine respiratory disease complex (PRDC). Vet. Microbiol. 215:71-76. https://doi. org/10.1016/j.vetmic.2018.01.004.

Kekarainen T, Segalés J. (2015) Porcine circovirus 2 immunology and viral evolution. Porc. Health. Manag. 1:17. https://doi.org/10.1186/s40813-015-0012-z.

Kim S-C, Nazki S, Kwon S et al. (2018) The prevalence and genetic characteristics of porcine circovirus type 2 and 3 in Korea. BMC Vet. Res. 14:294. https://doi.org/10.1186/ s12917-018-1614-x.

Klaumann F, Correa-Fiz F, Franzo G et al. (2018) Current knowledge on porcine circovirus 3 (PCV-3): A novel virus with a yet unknown impact on the sSwine Industry. Front. Vet. Sci. 5:315. https://doi.org/10.3389/ fvets.2018.00315.

Klaumann F, Dias-Alves A, Cabezón O et al. (2019) Porcine circovirus 3 is highly prevalent in serum and tissues and may persistently infect wild boar (Sus scrofa scrofa). Transbound Emerg. Dis. 66:91-101. https://doi. org/10.1111/tbed.12988.

Klaumann F, Franzo G, Sohrmann M et al. (2018) Retrospective detection of Porcine circovirus 3 (PCV-3) in pig serum samples from Spain. Transbound Emerg. Dis. 65:1290-1296. https://doi.org/10.1111/tbed.12876.

$\mathrm{Ku} \mathrm{X}$, Chen F, Li P et al. (2017) Identification and genetic characterization of porcine circovirus type 3 in China. Transbound Emerg. Dis. 64:703-708. https://doi. org/10.1111/tbed.12638.

Kwon T, Yoo SJ, Park C-K, Lyoo YS. (2017) Prevalence of novel porcine circovirus 3 in Korean pig populations. Vet. Microbiol. 207:178-180. https://doi.org/10.1016/j. vetmic.2017.06.013.

Liu Y, Meng H, Shi L, Li L. (2019) Sensitive detection of porcine circovirus 3 by droplet digital PCR. J. VET. Diagn. Invest. 31:604-607. https://doi. org/10.1177/1040638719847686.

López-Lorenzo G, Díaz-Cao JM, Prieto A et al. (2019) Environmental distribution of Porcine Circovirus Type 2 (PCV2) in swine herds with natural infection. Sci. Rep. 9:14816. https://doi.org/10.1038/s41598-019-51473-6.

Lv Q, Wang T, Deng J et al. (2020) Genomic analysis of porcine circovirus type 2 from southern China. Vet. Med. Sci. 6:875-889. https://doi.org/10.1002/vms3.288.

Mukherjee P, Karam A, Barkalita L et al. (2018) Porcine circovirus 2 in the North Eastern region of India: Disease prevalence and genetic variation among the isolates from areas of intensive pig rearing. Acta Tropica. 182: 
166-172. https://doi.org/10.1016/j.actatropica.2018.02. 025 .

Opriessnig T, Xiao C-T, Gerber PF, Halbur PG. (2014) Identification of recently described porcine parvoviruses in archived North American samples from 1996 and association with porcine circovirus associated disease. Vet. Microbiol. 173:9-16. https://doi.org/10.1016/j.vetmic.2014.06.024.

Oropeza-Moe M, Oropeza Delgado AJ, Framstad T. (2017) Porcine circovirus type 2 associated reproductive failure in a specific pathogen free (SPF) piglet producing herd in Norway: a case report. Porc. Health. Manag. 3:25. https://doi.org/10.1186/s40813-017-0072-3.

Ouyang T, Niu G, Liu X et al. (2019) Recent progress on porcine circovirus type 3. Infection, Genet. Evol. 73:227233. https://doi.org/10.1016/j.meegid.2019.05.009.

Palinski R, Piñeyro P, Shang P et al. (2017) A Novel Porcine Circovirus Distantly Related to Known Circoviruses Is Associated with Porcine Dermatitis and Nephropathy Syndrome and Reproductive Failure. J. Virol. https://doi. org/10.1128/JVI.01879-16.

Phan TG, Giannitti F, Rossow S et al. (2016) Detection of a novel circovirus PCV3 in pigs with cardiac and multisystemic inflammation. Virol. J. 13:184. https://doi.org/ 10.1186/s12985-016-0642-z.

Prinz C, Stillfried M, Neubert LK, Denner J. (2019) Detection of PCV3 in German wild boars. Virol J 16:25. https://doi. org/10.1186/s12985-019-1133-9.

Qi S, Su M, Guo D et al. (2019) Molecular detection and phylogenetic analysis of porcine circovirus type 3 in 21 Provinces of China during 2015-2017. Transbound Emerg. Dis. 66:1004-1015. https://doi.org/10.1111/tbed. 13125.

Rodrigues ILF, Cruz ACM, Souza AE et al. (2020) Retrospective study of porcine circovirus 3 (PCV3) in swine tissue from Brazil (1967-2018). Braz. J. Microbiol. 51:13911397. https://doi.org/10.1007/s42770-020-00281-6.

Gerilovych AP, Bolotin VI, Rudova NG et al. (2011) Etiological structure of circovirus-associated diseases of pigs in farms of the Eastern region of Ukraine. Bull. Agric. Sci. (1):34-36. (in Ukrainian).

Saporiti V, Cruz TF, Correa-Fiz F et al. (2020) Similar frequency of Porcine circovirus 3 (PCV-3) detection in serum samples of pigs affected by digestive or respiratory disorders and age-matched clinically healthy pigs. Transbound Emerg Dis 67:199-205. https://doi. org/10.1111/tbed.13341.

Saporiti V, Huerta E, Correa-Fiz F et al. (2020) Detection and genotyping of Porcine circovirus 2 (PCV-2) and detection of Porcine circovirus 3 (PCV-3) in sera from fattening pigs of different European countries. Transbound Emerg. Dis. 67:2521-2531. https://doi.org/ 10.1111/tbed.13596.

Saporiti V, Valls L, Maldonado J et al. (2021) Porcine
Circovirus 3 Detection in Aborted Fetuses and Stillborn Piglets from Swine Reproductive Failure Cases. Viruses. 13:264. https://doi.org/10.3390/v13020264.

Saraiva G, Vidigal P, Assao V et al. (2019) Retrospective Detection and Genetic Characterization of Porcine Circovirus 3 (PCV3) Strains Identified between 2006 and 2007 in Brazil. Viruses. 11:201. https://doi.org/10.3390/v11030201.

Savic B, Milicevic V, Radanovic O et al. (2020) Identification and genetic characterization of porcine circovirus 3 on pig farms in Serbia. Arch. Virol. 165:193-199. https:// doi.org/10.1007/s00705-019-04455-y.

Segalés J, Allan GM, Domingo M. (2005) Porcine circovirus diseases. Anim Health Res Rev 6:119-142. https://doi. org/10.1079/AHR2005106.

Serena MS, Cappuccio JA, Barrales H et al. (2020) First detection and genetic characterization of porcine circovirus type 3 (PCV3) in Argentina and its association with reproductive failure. Transbound Emerg. Dis.. 13893. https://doi.org/10.1111/tbed.13893.

Shen H, Liu X, Zhang P et al. (2018) Genome characterization of a porcine circovirus type 3 in South China. Transbound Emerg. Dis. 65:264-266. https://doi.org/10.1111/tbed. 12639.

Shen H-G, Halbur PG, Opriessnig T. (2012) Prevalence and phylogenetic analysis of the current porcine circovirus 2 genotypes after implementation of widespread vaccination programmes in the USA. J. Gener. Virol. 93: 1345-1355. https://doi.org/10.1099/vir.0.039552-0.

Stadejek T, Woźniak A, Miłek D, Biernacka K. (2017) First detection of porcine circovirus type 3 on commercial pig farms in Poland. Transbound Emerg. Dis. 64:1350-1353. https://doi.org/10.1111/tbed.12672.

State Statistic Service of Ukraine (2021). http://www.ukrstat. gov.ua. Accessed 15 Sep 2021

Gerilovych AP. (2009) Methodology for calculation and theoretical verification of oligonucleotide quality for detection of nucleic acids of animal pathogens based on polymerase chain reaction. Bull. Vet. Bioteh. (14):56-69. (in Ukrainian).

Streltsova YaB. (2018) The modern epizootology for porcine circovirus disease. https://doi.org/10.25725/VET.SAN. HYG.ECOL.201801022.

Sukmak M, Thanantong N, Poolperm P et al. (2019) The retrospective identification and molecular epidemiology of porcine circovirus type 3 (PCV 3 ) in swine in Thailand from 2006 to 2017. Transbound Emerg. Dis. 66:611-616. https://doi.org/10.1111/tbed.13057.

Varela APM, Loiko MR, Andrade J da S et al. (2021) Complete genome characterization of porcine circovirus 3 recovered from wild boars in Southern Brazil. Transbound Emerg. Dis. 68:240-247. https://doi.org/10.1111/tbed.13679.

Vargas-Bermudez DS, Campos FS, Bonil L et al. (2019) First detection of porcine circovirus type 3 in Colombia 
and the complete genome sequence demonstrates the circulation of PCV $3 a 1$ and PCV 3a2. Vet. Med. Sci. 5:182-188. https://doi.org/10.1002/vms3.155.

Wang Y, Noll L, Lu N et al (2020) Genetic diversity and prevalence of porcine circovirus type 3 (PCV3) and type 2 (PCV2) in the Midwest of the USA during 2016-2018. Transbound Emerg Dis 67:1284-1294. https://doi. org/10.1111/tbed.13467

Ye X, Berg M, Fossum C et al. (2018) Detection and genetic characterisation of porcine circovirus 3 from pigs in Sweden. Vir. Gen. 54:466-469. https://doi.org/10.1007/ s11262-018-1553-4.

Yuzhakov AG, Raev SA, Alekseev KP et al. (2018) First detection and full genome sequence of porcine circovirus type 3 in Russia. Vir. Gen. 54:608-611. https://doi.org/ 10.1007/s11262-018-1582-z.

Zhang S, Wang D, Jiang Y et al. (2019) Development and application of a baculovirus-expressed capsid proteinbased indirect ELISA for detection of porcine circovirus 3 IgG antibodies. BMC Vet. Res. 15:79. https://doi. org/10.1186/s12917-019-1810-3.

Zheng S, Wu X, Shi J et al. (2018) Rapid specific and visible detection of porcine circovirus type 3 using loopmediated isothermal amplification (LAMP). Transbound Emerg. Dis. 65:597-601. https://doi.org/10.1111/ tbed. 12835 . 